\title{
Antibacterial Coatings for Improving the Performance of Biomaterials
}

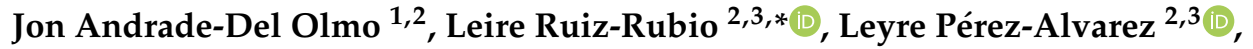 \\ Virginia Sáez-Martínez ${ }^{1}$ and José Luis Vilas-Vilela ${ }^{2,3}$ (D) \\ 1 i+Med S. Coop, Parque Tecnológico de Alava. Albert Einstein 15, nave 15, 01510 Miñano, Spain; \\ jandrade@imasmed.com (J.A.-D.O.); vsaez@imasmed.com (V.S.-M.) \\ 2 Macromolecular Chemistry Group (LABQUIMAC), Department of Physical Chemistry, Faculty of Science \\ and Technology, University of the Basque Country, UPV/EHU, Barrio Sarriena, s/n 48940 Leioa, Spain; \\ leyre.perez@ehu.eus (L.P.-A.); joseluis.vilas@ehu.es (J.L.V.-V.) \\ 3 BCMaterials, Basque Center for Materials, Applications and Nanostructures, UPV/EHU Science Park, \\ 48940 Leioa, Spain \\ * Correspondence: leire.ruiz@ehu.eus; Tel.: +34-94-6017-972
}

Received: 19 December 2019; Accepted: 30 January 2020; Published: 4 February 2020

\begin{abstract}
Biomedical devices have become essential in the health care. Every day, an enormous number of these devices are used or implanted in humans. In this context, the bacterial contamination that could be developed in implanted devices is critical since it is estimated that infections kill more people than other medical causes. Commonly, these infections are treated with antibiotics, but the biofilm formation on implant surfaces could significantly reduce the effectiveness of these antibiotics since bacteria inside the biofilm is protected from the drug. In some cases, a complete removal of the implant is necessary in order to overcome the infection. In this context, antibacterial coatings are considered an excellent strategy to avoid biofilm formation and, therefore, mitigate the derived complications. In this review, the main biomaterials used in biomedical devices, the mechanism of biofilm formation, and the main strategies for the development of antibacterial coatings, are reviewed. Finally, the main polymer-based strategies to develop antibacterial coatings are summarized, with the aim of these coatings being to avoid the bacteria proliferation by controlling the antibacterial mechanisms involved and enhancing long-term stability.
\end{abstract}

Keywords: antibacterial coatings; contact killing; active surfaces

\section{Introduction}

Ever-increasing clinical demand, added to the advances in science and technology, have raised interest in new biomaterials for implants and medical devices [1]. Nowadays, biomedical devices are essential for the health of a large part of the world's population. Implants are used every day in several medic disciplines such as dentistry, orthopedics, urology and several surgical specialties (neuro, cardiovascular surgery etc.), among others. The materials used in the fabrication of biomedical devices could be of a different nature depending on the specific requirement that should fulfil, in the Table 1 are summarized some of the most common implants [2-4]. 
Table 1. Summary of some of the main biomedical devices and materials used in them.

\begin{tabular}{ccc}
\hline Implant & Material & Reference \\
\hline Heart valve & $\begin{array}{c}\text { Titanium and its alloys, graphite, } \\
\text { polyester, cobalt-chromium alloys }\end{array}$ & {$[5]$} \\
\hline Urinary catheter & $\begin{array}{c}\text { Latex, silicone, nylon, } \\
\text { polyethylene terephthalate }\end{array}$ & {$[6]$} \\
\hline Peritoneal catheter & Silicone, polyurethane & {$[7]$} \\
\hline Stents & $\begin{array}{c}\text { Cobalt-chromium, titanium and } \\
\text { magnesium alloys, diamondlike } \\
\text { carbon }\end{array}$ & {$[8]$} \\
\hline Dental & $\begin{array}{c}\text { Titanium, zirconia and } \\
\text { cobalt-chromium alloys, alumina, } \\
\text { bioglass }\end{array}$ & {$[9]$} \\
\hline Contact and intraocular lenses & $\begin{array}{c}\text { Polymethylmethacrylate, } \\
\text { polyhydroethylmethacrylate, } \\
\text { silicone, acrylic }\end{array}$ & {$[10,11]$} \\
\hline Knee and hip & $\begin{array}{c}\text { Titanium, platinum, silicone, } \\
\text { polytetrafluoroethylene }\end{array}$ & {$[12]$} \\
\hline $\begin{array}{c}\text { Stainless steel, titanium and } \\
\text { cobalt-chromium alloys, } \\
\text { polyethylene, ceramics }\end{array}$ & {$[13,14]$}
\end{tabular}

\subsection{Common Materials Used in Biomedical Devices}

The number of different materials used in the development of biomedical devices is enormous. Biomedical devices could be implantable (knee/hip cochlear implants, heart valves, stents, etc.) or non-implantable (contact lenses, catheters, facture fixation devices, etc.). Also, in some cases, they could be absorbable such as some sutures, implants or stents $[4,15]$. Considering the device lifetime and their use, ceramics, polymers and metal alloys are used to fabricate biomedical devices.

\subsubsection{Ceramic}

Ceramic, usually known as bioceramic when used as biomaterial, is used to repair or replace damaged parts of musculoskeletal systems. Alumina $\left(\mathrm{Al}_{2} \mathrm{O}_{3}\right)$, zirconia $\left(\mathrm{ZrO}_{2}\right)$ and diamond-like carbon (DLC) are considered biologically inert [16]. Zirconia presents good mechanical strength, toughness, fatigue resistance) and chemical properties [17]. In addition, its biocompatibility, osseoconductivity, and tendency to reduce plaque accumulation eases the bone formation when the tissues are in contact with the zirconia [18]. The excellent biological and mechanical properties (elastic behaviour, a hardness around $90 \mathrm{GPa}$ and modulus around $515 \mathrm{GPa}$ ) of DLC have attracted the interest of researchers in developing biomedical devices based on it [19]. DLC presents excellent tribological properties, is resistant to corrosion, biocompatible and hemocompatible [20].

\subsubsection{Metal and Metal Alloys}

Metals (usually as alloys) mainly used for implant fabrication can be divided in three groups, titanium alloys, stainless steel and cobalt-chromium alloys. In particular, type 316L stainless steels, cobalt-chromium alloys, bare titanium, and Ti6Al4V alloys are the most used materials [21]. Type 316L stainless steel, an iron-based alloy that contains iron, chromium, and nickel, is the type widely used as stainless steel for implants. Many trauma temporary devices (fracture plates, screws and hip nails) are made with this material because of its availability, lower cost, biocompatibility and great strength. However, the nickel content in some of the stainless steels could be problematic due to the toxicity for human, so the usage of some of these derivatives is limited [21]. Titanium and its alloys, especially Ti6Al4V, are extensively used as the main material of dental and orthopedic implants. Ti6Al4V alloy 
presents good corrosion resistance and good strength and low elastic modulus, it does not produce allergic reactions, and is non-toxic. Nowadays, titanium and its alloys are the most frequently used materials for dental implants, but they are slowly being replaced by zirconia [22].

\subsubsection{Polymers}

Polymer-based biomaterials are used extensively in medical devices due to their advantageous properties. Among these properties, it is important to note their easy fabrication, inexpensiveness compared to metal materials, and their biocompatibility. In addition, many added properties (mechanical, electrical, chemical, or thermal) could be improved by using polymer-based composites. Main polymeric biomaterials include polymethylmethacrylate (PMMA), polyethylene (PE), ultrahigh molecular weight polyethylene (UHMWPE) polypropylene (PP), polytetrafluoroethylene (PTFE) and poly(ethylene terephthalate) (PET) polyvinylidene fluoride (PVDF), polydimethylsiloxane (PDMS) or polyurethane (PU), among others. As examples, PMMA is used as bone cement and for intraocular lenses and PET and polytetrafluoroethylene (PTFE) are used in artificial ligaments [23].

It is important to note that these families of materials can also be mixed to obtain extensively used composite materials. The use of composites as biomaterials has been greatly extended, since one of the basis of these materials is the advanced properties compared to bare materials [24-26].

All the described materials (ceramics, metals and polymers) are excellent for the development of biomedical devices. However, commonly, when they are implanted, there is a chance of a patient suffering an infection associated to their implantation or/and diseases derived from this complication. Indeed, a competition for implant surface colonization between the host (human tissue) and bacteria occurs in every implantation process. This process was described by ZoBell et al., establishing in their studies that bacteria prefer to colonize a solid substrate, with the bacteria being present on surfaces dramatically higher than in the surrounding medium [27]. Additionally, fungal and mixed infections, that is, infection originated both by bacteria and fungi, have increased lately [28]. Therefore, the development of antibacterial coatings for the different substrates, ceramic, metal and polymeric substrates, is crucial to reduce bacterial adhesion and proliferation.

After analyzing the main biomaterials used in biomedical devices, the biofilm formation including the description of the different paths involved in this process are described in this review. Finally, some of the most promising approaches reported to date have been summarized. The aim of this work is to summarize the main antibacterial methodologies used in the development of the most recent and/or relevant studies.

\section{Biofilm Formation}

Biofilm is a term used to describe an irreversible attachment of an organized aggregate of communities of microorganisms to a surface of materials or to each other. It is embedded in an extracellular polymeric matrix (EPM) which will not be removed unless this occurs quickly [29]. Biofilms have raised special awareness within the health industry for health and safety reasons. In fact, it is thought that about $65 \%-70 \%$ of all bacterial infections in medical devices in the body are associated with bacterial biofilms [30]. This bacterial coloniza tion can cause a failure in these implants, with a need of explanation and thus, can cause serious health problems particularly in critically ill patients.

Nowadays, the biofilm formation mechanism is a complex and multifunctional process which involves several steps from the initial bacterial attachment to a surface, to the maturation and dispersion of surface-adhered bacteria. The many microbial colonies that form the biofilm are separated by channels composed almost entirely of water. The life cycle of biofilms is governed by the water content because it controls the flow of essential nutrients inside biofilms and the stability of biofilms is controlled by the viscoelastic properties of the EPM [31].

Biofilm formation is a very complex and complicated process composed of many steps. Even so, it can be summarized in four main stages, which are outlined in Figure 1 and explained below. 


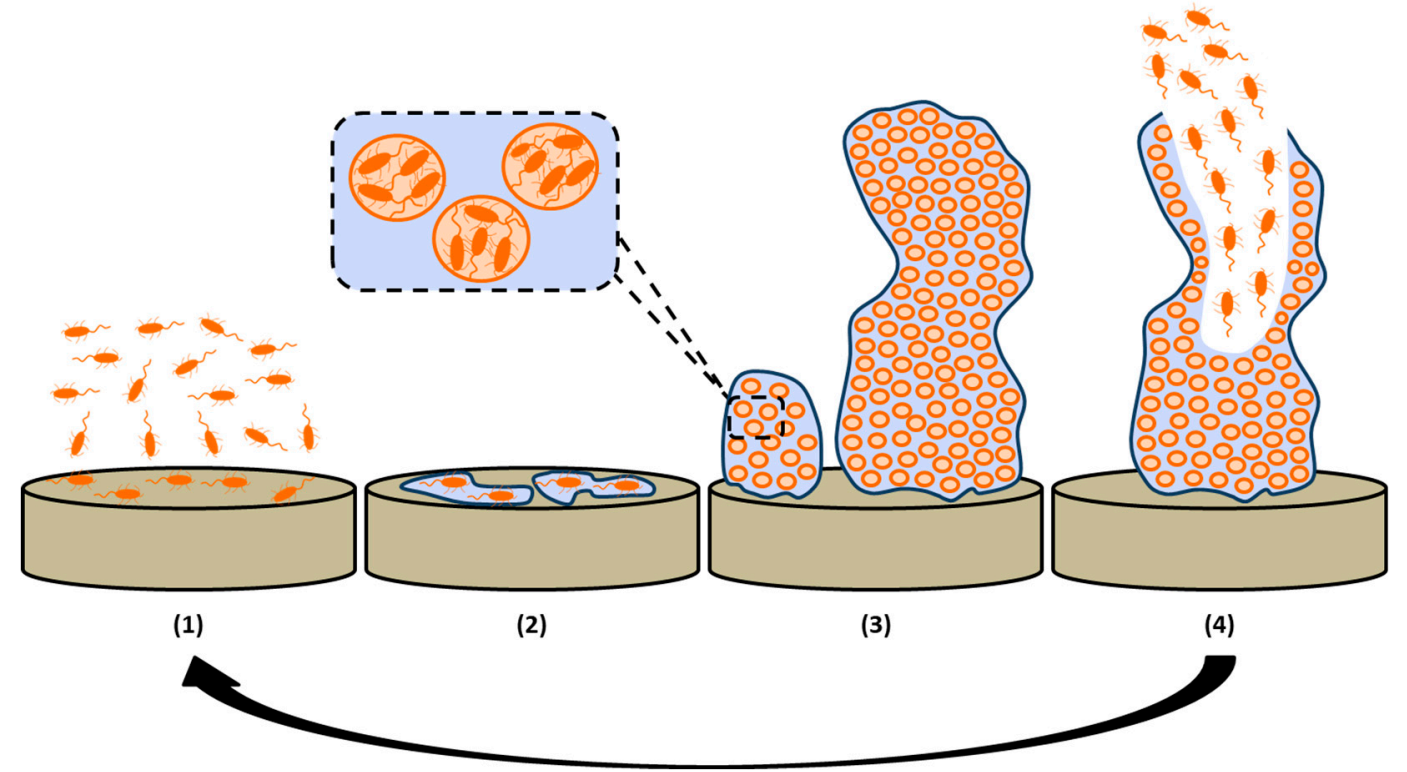

Figure 1. Schematic representation of the five main stages of biofilm formation. (1) Reversible attachment of bacteria cells, (2) irreversible attachment due to extracellular polymeric matrix (EPM) secretion, (3) development of biofilm structure, and (4) maturation and dispersion of biofilm.

\subsection{Reversible Attachment of Bacteria Cells}

A bacterial infection can be caused by contamination during implantation when a medical device carrying external microorganisms is implanted into the body. These are often transferred from the skin of the patient/clinical staff, surgical equipment and material, or polluted disinfectants. At this first stage of biofilm formation, the microorganisms are quickly adhered to the surface of medical devices through their flagella. The factors which can contribute to this initial attachment are physical forces like London-Van der Waals forces and electrostatic interactions, among others [32].

\subsection{Irreversible Attachment due to Extracellular Polymeric Matrix (EPM) Secretion}

Once bacteria are attached to medical devices surface, they adhere irreversibly by secreting the EPM, an extracellular matrix of protein polymers and polysaccharides whose thickness is between 0.2 and $1.0 \mu \mathrm{m}$. The formation of this EPM provides a higher stability to the biofilm due to the attractive forces between microorganisms, which are reinforced in this environment. In fact, this specific atmosphere leads to the aggregation of microorganisms in little micro-aggregates leading to the formation of a microbial biofilm on a solid surface [33].

\subsection{Development of Biofilm Structure}

The EPM encases the cells leading to the intercellular adhesion and formation of bacterial communities known as biofilm, which continues to grow and mature. Once microorganisms are adhered to the surface of implants in a stable way, microbial cells start a proliferation process and bacterial colonies are created. These colonies further develop into bigger colonies enclosed by the EPM, which acts as a barrier and protects bacteria from adverse conditions. From $5 \%-35 \%$ of the biofilm total volume is constituted by the microorganisms while the remaining volume corresponds to the EPM [34].

\subsection{Maturation and Dispersion of Biofilm}

Within the EPM, intercellular signaling between bacteria takes place. This mechanism provides self-organization and regulation of some features of microbial cells, such as biofilm formation, production of EPM and so on. Once the biofilm reaches a critical mass (matured biofilm), it generates 
microorganisms, which are ready for the disruption and release from the biofilm and then, they can further recolonize and repeat the process again [35].

\section{Antibacterial Mechanisms}

Different strategies have been investigated in the last few years to prevent bacterial adhesion and subsequent biofilm formation. Most of them are related to surface design and can be classified in broad terms as (Figure 2): (1) bacterial repelling and (2) bacteria killing surfaces [28]. The mechanism of action of the first one is based on the prevention of biofilm formation, while killing approaches correspond to bactericidal surfaces that lead to the disruption of bacterial cells on contact, leading to cell death. Regarding killing surfaces, it is worth discriminating those based on surfaces that release antibacterial agents in a control manner, which kill both adhered bacteria and bacteria from the surroundings. These coatings act as reservoirs of bactericide agents and allow their local delivery, which enables a more efficient action.

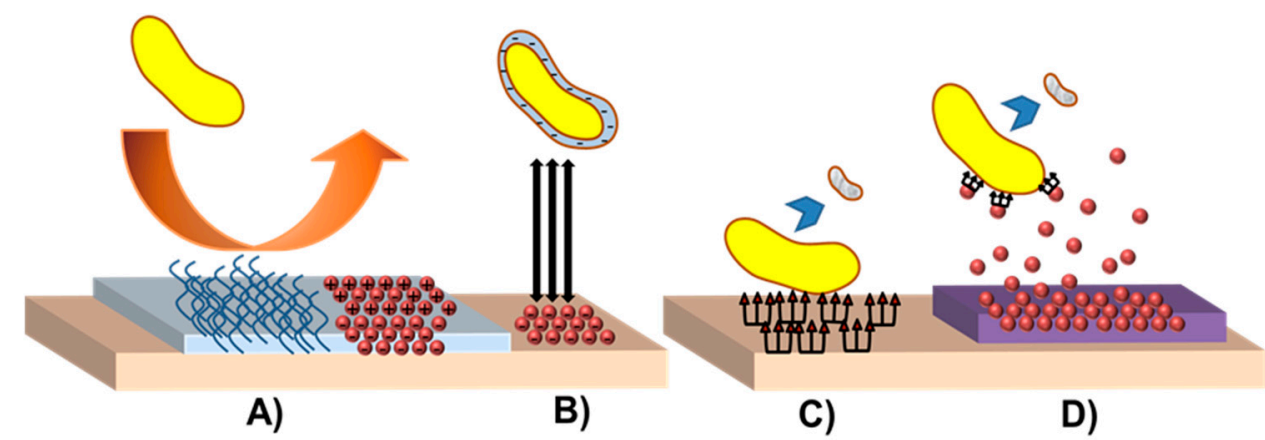

Figure 2. General strategies to the development of antibacterial surfaces based on: (A) steric, (B) electrostatic, (C) Contact killing and (D) biocide release effects.

This last approach corresponds to the oldest antibacterial surface design based on the leaching of biocides that has led to a growing concern on the resulting bacteria resistance as a consequence of the abusive use of biocides [36]. In addition, the long-term effectiveness of thus designed antibacterial surfaces is restricted by the limited amount of bactericide that can be loaded in the surface. Unlikely, non-releasing contact killing surfaces offer a prolonged action along the time, although adsorption of bacterial membranes usually cover the killing functionalities on the surface, limiting their effectiveness [37]. The first approach based on reducing attachment can be performed by modification of surfaces to obtain steric or electrostatic repulsion or a hierarchical topography that usually results in being unstable over long periods of times. Thus, a unique strategy to prepare ideal antibacterial surfaces does not exit and this fact encourages increasing investigation of the combination of different approaches and the development of new antibacterial surfaces. For this, researchers found inspiration on nature in which antifouling and self-cleaning surfaces are found in some insect wings, animals skins, and lotus leaves [38]. Mimicking these natural surfaces has revealed that microand nanoscale hierarchical topographies together with non-fouling surface chemistries and biocide releasing can lead to successful results [39].

Accordingly, different methods have been followed to prepare antibacterial surfaces. Most of them can be classified as physical or chemical modifications that include adsorption, self-assembled monolayers (SAMs), grafting, cross-linking, or chemical linkage, as well as plasma treatments [40]. SAMs correspond to spontaneous assemblies of adsorbed molecules on surfaces that lead to organized, ordered and compact structures in the form of coherent monolayers. By contrast, grafting and crosslinking are examples of chemical linkages. They correspond to the linkage onto or from the surface of specific molecules leading, generally, to heterogeneous modifications. This is also the case of plasma treatments in which surface etching or activation takes place by reaction with plasma. 


\subsection{Bacteria Repelling Surfaces}

These kinds of surfaces includes those that imply the development of different approaches to diminish bacteria adhesion to surface such as repelling or resisting bacteria attachment. They are the so-called antibiofouling surfaces. Their action is based on the presence of a specific surface topography or/and chemistry that is not favorable to the microorganisms. This is the case of hydrophilic surfaces covered by a highly hydrated surface layer that resist bacterial attachment. Poly(ethylene glycol) (PEG) segments and zwitterionic units anchored at surfaces are the most representative examples of these kinds of antibacterial hydrophilic surfaces and they have been intensively studied. Alternatively, superhydrophobic surfaces have also demonstrated successful antifouling properties related to an air layer between the aqueous medium and the surface that reduce cells attachment [41]. Accordingly, bacteria repelling action can be described and classified based on three different effects: (i) steric, (ii) electrostatic and (iii) superhydrophobic effect, that can be observed in hydrophilic, charged and superhydrophobic surfaces, respectively.

\subsubsection{Hydrophylic Surfaces}

Differences in surface wettability can considerably affect the adhesion of bacteria to the surfaces. Indeed, surface free energy influences considerably bacterial adhesion showing that materials with low surface energy display higher interaction with bacteria than those with higher surface free energy [36]. It is known that hydrophilic surfaces prevent the attachment of cells and bacteria due to the fact that they are coated by a layer of water molecules and consequently, cells and bacteria cannot be anchored. This water layer is highly linked by H-bonding to the hydrophilic material and it plays as a physical and energetic barrier that must be overcome for cells or bacteria adsorption. Thus, bacteria adsorption requires, firstly, the expulsion of water from surface, this is, a reduction of the free energy barrier derived from the entropic effect caused by the destruction of the hydration layer [19]. Thus, highly hydrophilic coatings provide a simple method to repel bacteria; consequently, different coatings of this kind have been explored in the last few years. Examples that can be cited are the development of superhydrophilic zeolites that were prepared as coating on titanium alloy surface and were revealed as an effective method to avoid bacteria attachment with a potential application in orthopedic implants [42], or superhydrophilic coatings constructed as a multilayer assembled by H-bonding between hydrophilic branched poly(ethylenimine) and poly(urethane acrylate) mixed with silica nanoparticles [43].

However, due to the entropic effect of bacterial adhesion, the robustness of the hydration layer is also influenced by the packaging on surface, which is determined by chain conformation when surfaces are decorated by polymeric chains. In these cases, the compression of superficial polymer chains with high conformational freedom would imply a loss of entropy that results in steric repulsion favoring the bacterial repulsion effect. Thus, steric repulsion is understood as an entropic effect aroused from an unfavorable change in free energy associated with the dehydration and the confinement of a flexible polymer chain [44].

Certainly, hydrophilic polymers can also reduce bacteria attachment to some extent, however, high antifouling properties are only acquired when steric repulsion complements surface hydration [40]. In this category, some highly hydrated polymers that have demonstrated a capacity to reduce bacterial adhesion by steric hindrance are worth highlighting. It is well known that poly(ethylene glycol) (PEG) on a surface exhibits a large exclusion volume effect and chain flexibility reducing protein and bacterial attachment.

Thus, since the late eighties PEG grafting demonstrated on hydrophobic polyurethane surfaces reduced significant bacterial adhesions [45]. More recently, silane-ended PEG was grafted efficiently onto stainless steel archwires for dental applications with varied polymer chain lengths (350-200,000 Da) and showed a significant decrease of the initial acidogenic bacteria adhesion [46]. PEG was also covalently grafted onto silazane polymers (PSZ) to develop antifouling surfaces to be used in marine environments. PEG-graft-PSZ coatings were crosslinked by hydrolysis-condensation reactions 
of alkoxysilane, Si-H and Si-N moieties. Prepared coatings showed excellent antifouling properties against Gram-negative Neisseria sp. and gram-positive Clostridium sp. which were closely related to the grafting density and chain length of PEG; the shorter the chains are and the higher the graft density is, the better the bacteria repellent properties that were measured [47].

PEG derivatives have been anchored on surfaces by different methods along the last years, mainly by simple adsorption [48] or covalent grafting. Nevertheless, it has been demonstrated that covalently linked PEG chains provide a long-term bacteria repelling action that is not observed for physisorbed PEG polymers [49]. Some authors have compared bacteria with 'mega-surfactants' that can displace physisorbed polymer from the surface, while covalently grafted PEG chains can remain stable [48]. Accordingly, this effect is more notorious for low molecular weight molecules that are quickly displaced when they are physisorbed, in comparison to polymeric molecules. In general, PEG immobilization by chemical grafting can be carried out by means of the so called "graft-to" or "graft-from" approaches, which correspond to the grafting of end-functionalized polymer chains to the solid substrate or the grafting reaction by polymerization from the surface, respectively [50]. The "graft-to-surface" methods, either by physical adsorption, or chemical linkage result in more heterogeneous coverage of the surfaces in comparison to "graft-from-surface" approaches, that makes this last methods in a more promising method in the preparation of PEG-derived antibacterial coatings [40].

Specifically, surfaces obtained with a high density of grafting receive the name of polymer brushes. Polymer brushes are created by the grafting of polymer chains with a great density on the surface that provide properties different to those present in grafted polymer chains at low grades of density, such as mechanical stability, tunable thickness and grafting density, feasibility to modification and bacterial anti-adhesive properties. Polymer brushes provide ideal systems for preparing and studying antifouling materials [51].

PEG or PEO brushes have been grafted to different surfaces observing a clear reduce of bacteria adhesion [52]. For example, PEO (9800 Da) was covalently grafted on glass and silica surfaces and a decrease of $98 \%$ of adhered Staphylococci and Escherichia coli was determined [53]. Hierarchical polymer brushes were prepared by the chemical grown of a PEG with high packing density followed by a quaternary ammonium compound (QAC) on a top coating by surface-initiated photoiniferter-mediated polymerization. This coating showed a permanent antimicrobial performance and PEG antifouling coverage allowed a great reduction of the amount of bactericide [46].

Despite the proven bacteria-repellent properties of PEG, PEG-based coatings have also shown disadvantages, such as their ability to be oxidized in biochemical media. As a consequence, great efforts have been made to find substitutes with stability higher than PEG [40].

Poly(2-alkyl-2-oxazoline) are neutral and hydrophilic polymers which have also showed similar non-fouling properties to PEG [52]. As example, a poly(2-methyl-2-oxazoline) (PMOXA) coating showed great stability in sea water and marine anti-fouling properties. Cited stable coating was obtained by ultraviolet (UV) crosslinking of previously included methyl acrylate end groups on an specifically synthesized (2-methyl-2-oxazoline) macromonomer [54].

Polyacrylamide (PAAm) brushes have been also developed on different substrates, such as silicon or gold wafer, showing bacteria-repellent properties equivalent or even those of improved homologous PEG brushes [52].

Similarly, self-assembled monolayers of oligo(ethylene glycol) (OEG), which have been intensively investigated to elucidate the mechanism of the protein resistance action of PEG, show also a significant bacteria repellent behaviour. In addition, these monolayers present as advantages, compared to PEG, a controlled chain length and interface [55].

\subsubsection{Charged Surfaces}

The bacterial cell surface acquires typically a negative charge from the ionization of carboxyl, phosphate. Consequently, electrostatic repulsion arises when negatively charged surfaces and bacteria 
cells approach that explains a general reduction of bacterial adhesion [36]. As a consequence of the strong electrostatic forces the shape of adhered bacteria has been shown to be disturbed [51].

Interestingly, surfaces functionalized with zwitterionic polymers that show equally distributed anionic and cationic groups along their backbone have displayed antifouling properties. This fact is ascribed to a tightly bound water layer adsorbed at the surface that represents, as in the case of PEG, a physical and energetic barrier that reduces bacteria adsorption. In comparison with hydrophilic polymers, bound water interaction by ionic salvation is stronger than the H-bonding linkage water layer, which reinforces the antifouling nature of zwitterionic surfaces [40]. Besides the steric hindrance effect of this hydration layer, the cationic groups can also kill bacteria by contact, as described below, which gives added value to zwitterionic polymers as antibacterial coatings [40].

In addition, zwitterionic polymers are more versatile than PEG functionalization offering a broader range of chemical functionalities. Typical anionic groups included in zwitterionic polymers are carboxylates, sulfonates and phosphates, while quaternary ammonium, phosphonium, pyridinium and imidazolium represent the usually employed cationic groups in this kind of polymer. Poly(carboxybetaine) (PCB), poly(phosphataine) (PPB) and poly(sulfobetaine) (PSB), lie in the category of zwitterionic polymers because they contain, on the one hand, cationic quaternary ammonium salt (QAS) and, on the other hand, anionic carboxylate, phosphate and sulfate groups, respectively. For these reasons, these polymers have been widely employed as antibacterial coatings [56].

Zwiterionic polymers have been applied for the preparation of antibacterial coatings for membranes, fibres and hydrogels. For example, polysulfone ultrafiltration-supporting membranes were coated with an antibacterial zwitterionic polyamide thin film obtained by interfacial polymerization of N-aminoethyl piperazine propane sulfonate monomer with tri-mesoyl chloride (TMC) [57]. Poly(sulfobetaine methacrylate) (PSBMA) was synthesized also in the form of fibrous membranes by a multistep procedure consisted on a polymerization, electrospinning and photocrosslinking process that allows stability in water (crosslinking) and porous structure (electrospinning). The prepared membranes showed strong resistance to Gram-negative P. aeruginosa and Gram-positive S. epidermidis adhesion [58].

Sulfopropylbetaine coating has been reported as a rapid and environment-friendly finishing method of cotton fibres after its chemical modification in the form of isocyanate-coupled sulfopropylbetaine (NCO-sulfopropylbetaine). Final cotton fibres were shown to resist bacteria attachment and improve moisture/air permeability and mechanical properties [59]. Most recently, polyvinylamine was functionalized with zwitterionic sulfobetaine for the finishing of both poly(ethylene terephthalate) (PET) and cotton fibres, showing an efficient inhibition of bacteria adhesion, specially against Staphylococcus aureus [60].

Zwitterionic poly(sulfobetaine methacrylate) hydrogels crosslinked with poly(ethylene glycol)dimethacrylate by simultaneous crosslinking and photopolymerization, were revealed as a promising candidate for the next-generation of wound dressings due to their antibacterial and enhanced mechanical properties [61].

Zwitterionic polymers have been incorporated also as brushes on different surfaces. Brushes of poly(carboxybetaine methacrylate) (PCBMA) were grafted to glass surface and demonstrated the reduction of $P$. aeruginosa bacteria [62].

\subsubsection{Superhydrophobic Surfaces}

Bacterial adhesion has been also investigated for hydrophobic surfaces but only superhydrophobic surfaces are well known for their bacteria antifouling ability. Superhydrophobic surfaces are those that present a water contact angle higher than $150^{\circ}$, and consequently are difficult to wet. Superhydrophobicity decreases the adhesion force between bacteria and the surface and facilitates the removal of initially adhered bacteria before the biofilm formation. This non-wetting nature of superhydrophobic surfaces has promoted different properties such as antireflectivity or self-cleaning which has broadened the applicability of these surfaces [63]. 
Superhydrophobicity usually implies a heterogeneous water wetting in which an air layer is distinguished between the surface and the droplet of water (as described Wenzel theory). The ability to reduce bacterial adhesion and promote easy removal of attached bacteria has been ascribed to this air layer between the liquid-solid interfaces [36].

Generally, superhydrophobicity is a result of the combination of a hierarchical topography in the micrometer/submicrometer scale, and a chemical composition that enables a low energy surface [36]. This combination is inspired from nature and is known as the Lotus leaf effect in which water droplets do not wet and rolls off easily [64]. This is a consequence of a dual topography on a low-energy surface constituted of epicuticular wax crystalloids with nanometric dimensions uniformly covering a regular microrelief of about $1-5 \mu \mathrm{m}$ in height. In addition to the hierarchical scale, the shapes of the topographic features are also important. For example, rounded-top protrusions have proved to be more effective than sharp edges in natural and synthetic surfaces [65].

The main disadvantage of the superhydrophobic surfaces that makes them a challenging issue, is their limited long-term application in actual situations. Micro-/nano-scaled features are not typically robust and their degradation usually leads to the lack of the superhydrophobicity of the surface. Similarly, low surface energy surfaces are characterized by a low durability as a consequence of the degradation by surface contamination or changes on surface chemistry as a response to reactions with the medium [66].

The methods for producing superhydrophobic anti-fouling coatings include photolithography, etching, chemical vapour deposition, layer-by-layer deposition, and/or a combination of them. As an example, Kim et al. designed a nanostructured surface on polymethyl methacrylate using the rigorous coupled-wave analysis (RCWA) method, a KrF excimer laser source for the patterning in the form of nanopillars followed by dry etching. Additionally, parabolic nanostructures were prepared by depositing silicon dioxide $\left(\mathrm{SiO}_{2}\right)$ via a thermal oxidation process followed by further modification via high-density plasma chemical vapour deposition using $\mathrm{SiO}_{2}$, and thermal nanoimprint lithography. Finally, prepared superhydrophobic films showed multifunctional applicability due to the achieved antireflective, antiwettable, and antibacterial properties [67].

The latter methods often require complex technology and harsh synthetic conditions limiting the applicability and often the type of the substrate to be coated. Many attempts have been made to simplify the preparation of superhydrophobic surfaces. Privett et al. synthesized a superhydrophobic fluoroalkoxysilane coating that demonstrated a capacity to reduce bacteria adhesion by mild conditions that enable the modification of any type and shape of substrates. It consists on a xerogel coating prepared from the simple mixture of nanostructured fluorinated silica nanoparticles, fluoroalkoxysilane, and a backbone silane [68].

Layer by layer $(\mathrm{LbL})$ has been also revealed as a simple methodology to prepare superhydrophobic coatings even in the absence of the need of any hierarchical topography. In this sense, the LbL deposition of poly(sodium 4-styrenesulfonate) (PSS)-1-octadecylamine (ODA) (PSS-ODA) complexes with poly(allylamine hydrochloride) (PAH)-sodium dodecyl sulfonate (SDS) (PAH-SDS) complexes has been exploited to develop superhydrophobic coating with self-healing ability that can be formed on different substrates regardless their size and shape [67].

\subsection{Active Action (Killing)}

Biofilms contribute to multiple problems as a consequence of the infections they cause and, therefore, novel methods are needed to fight against bacterial resistance. One mechanism is the use of surfaces which possess the ability to destroy and kill bacteria or microorganisms that are adhered to them [69]. Within antibacterial surfaces with killing activity, nanopatterned, contact-based and release-based mechanisms can be distinguished. In addition, there are some cases where the previously mentioned killing mechanisms are combined to increase bactericidal effect. 


\subsubsection{Contact-Based Antibacterial Surfaces}

Contact-active materials can be created by the adhesion to surfaces of specific biocides or antibacterial agents, which are capable of killing adhered bacteria. These antibacterial moieties can be attached to the surface of medical devices by irreversible covalent bonding or physical absorption, which endow devices with the so-called contact-killing property [70]. These antibacterial agents can be natural and synthetic chemicals like quaternary ammonium compounds (QACs), or other biomolecules obtained from natural resources including antimicrobial enzymes (AMEs), antimicrobial peptides (AMPs) and chitosan, among others.

The majority of contact-active materials employ synthetic QACs. QACs are positively charged organic molecules that contain four alkyl hydrophobic chains covalently attached to positively charged quaternary ammonium groups $\left(\mathrm{R}_{4} \mathrm{~N}^{+}\right)[71,72]$. The mechanism of their activity is believed to be a charge imbalance; in fact, the charge attraction between the positively charged QAC molecules $\left(\mathrm{Ca}^{2+}\right.$ and $\mathrm{Mg}^{2+}$ ions) and the negatively charged phospholipid bilayer of the bacteria cellular membrane lead to the disruption of the cellular membrane killing the microorganisms. Another process of QACs, which causes the destruction of bacteria, are the hydrophobic chains. In fact, they cause perturbations on cellular membrane when they are linked to entire surface area of bacteria leading to the loss of the cytoplasmic fluid's essential components [73].

There is a great variety of natural and synthetic QACs that can be easily attached by covalent bonding to surfaces which possess free hydroxyl functional groups $(-\mathrm{OH})$ onto its surface. The most typical QACs are quaternized alkyl pyridiniums as poly(vinyl-N-pyridinium bromide) [74], quaternary ammonium silane of 3-(trimethoxysilyl)-propyldimethyloctadecyl ammonium chloride [75], and quaternized poly(2-(dimethylamino ethyl) methacrylate) [76], among others. In all these cases, the results indicate that surfaces functionalized with these QACs make them effective killing surfaces.

These synthetic QACs can be substituted by some natural QACs, but the most used one because of its non-toxicity, biocompatibility and inherent antibacterial properties, is chitosan biopolymer. For example Chiono et al. [77] synthetized chitosan blends which were found to support bacteria proliferation making them promising candidates for use in nerve regeneration field. More recently, in 2018 Tan et al. [78] presented a study showing the efficiency of chitosan in biofilm formation inhibition against monocrobial and polymicrobial biofilms of Staphylococcus epidermis and Candida tropicalis.

Another way to promote a more natural, health care and environmentally friendly alternative than traditional synthetic QACs is the use of AMPs and AMEs biocides. AMPs are some peptides with fast bactericidal behavior which are part of the human immune system and AMEs are a group of enzymes with the ability to attack microorganisms or to catalyze some reactions which conclude in the killing of bacteria even at low concentrations. As a matter of fact, Onaizi et al. [79] studied a bactericidal coating incorporating AMPs with a broad spectrum of antibacterial activity for coating medical devices and implants. In 2013, Thallinger et al. [80] showed that the combination of different AMEs (proteases, polysaccharide-degrading enzymes, sensing enzymes, and so on) can converge their antimicrobial properties into the prevention of biofilm formation or the destruction of already adhered bacteria and microorganisms.

Apart from the aforementioned biocides, there are more examples of biocidal polymers in relevant literature for coating of medical devices. For instance, Meléndez-Ortiz et al. [81] demonstrated that poly(N-vinylimidazole) modified silicon rubber presents antibacterial activity against Pseudomonas aeruginosa. Moreover, in 2013, Lim et al. [82] published that arginine-tryptophan-rich peptides show no cytotoxicity for at least 21 days while they retain microbial functionality. Finally, Thoma et al. [83] studied ammonium ethyl methacrylate homopolymers and concluded that they possess an inhibitory effect against Gram-positive and Gram-negative bacteria.

So far, all the aforementioned scientific publications are laboratory-scale but there are already some industrial-scale available products in the market for their application in the medical field. For example, Microban ${ }^{\circledR}$ employs a technology consisting on coating medical devices and surgery components (including urological tools, medical electronics, catheter coatings and so on), which 
combines antibacterial properties with the advantageous benefits of parylene to kill detrimental bacteria [84]. Moreover, A\&B Biotechnology Laboratories ${ }^{\circledR}$ has developed a disinfectant based on AMEs that kills bacteria in health fields such as surfaces, surgery tools and medical components. This product is composed of a combination of AMEs and other active agents with a broad bactericide and fungicidal spectrum and low toxicity [85].

\subsubsection{Release-Based Antibacterial Surfaces}

Over the last few years, a broad range of release-based antibacterial surfaces has been developed. These systems are used as carriers for loaded biocides and bacteria destruction can be reached by their controlled release to the medium over time [86]. It is well-known that the most critical period of time for biofilm formation is the first $24 \mathrm{~h}$. So, in almost all cases, a short-term $(24 \mathrm{~h})$ release of biocidal agents is only needed to achieve antibacterial success of an implant. However, there are other cases where surfaces need particular long-term antibacterial efficiency and bacterial proliferation minimization with increased released capacity over time. This long-term (from days to months) release capacity of anti-microbial (long-time infection control), anti-proliferative (treatment of restenosis) [87] and anti-inflammatory (reduction of edemas) agents [88] are needed to treat diseases or infections, which need more time to be cured or eliminated.

There are too many strategies to fix these compounds into coated medical devices. The first is a simple method based on the dipping of a porous coating with the desired antimicrobial substance. Unfortunately, the release profile does not last for a long time and the previously loaded substance is quickly released due to the lack of interaction between coating and antimicrobial substances. However, this problem can be solved by using coating systems which enable the antimicrobial substance release over a longer time [89]. For that purpose, the coatings can be created using hydrogels or ceramics, which possess a larger pore size and specific morphological structures, or employ nanostructured polymeric systems such as, polyelectrolyte multilayers (PEM). These last can be built in a simple, versatile and low-cost way, growing alternating layers of opposite charges by dip-coating [90,91] or spray-coating, [92] based on the LbL technique. The most widely used released-based antibacterial surfaces and their examples are explained in Table 2.

Table 2. Examples of biocide-releasing systems for antimicrobial applications with biomedical applications.

\begin{tabular}{ccc}
\hline Released Antimicrobial Substance & Release Systems & References \\
\hline $\begin{array}{c}\text { Zinc oxide nanoparticles } \\
(\text { ZnO NP) }\end{array}$ & Poly $(N$-isopropylacrylamide $)$ & {$[93]$} \\
\cline { 2 - 3 } $\begin{array}{c}\text { Silver nanoparticles } \\
(\text { AgNP) }\end{array}$ & Silicone & {$[94]$} \\
\hline $\begin{array}{c}\text { Copper oxide nanoparticles } \\
(\text { CuO NP) }\end{array}$ & Poly(methyl methacrylate $)$ & {$[95]$} \\
\hline Zinc & Polyurethane & {$[96]$} \\
\hline Silver & Polysaccharides & {$[97]$} \\
\hline Copper & Polycaprolactone & {$[98]$} \\
\hline Selenium & Poly(methyl methacrylate $)$ & {$[97]$} \\
\hline Galium & Polyssacharides & {$[100]$} \\
\hline Gentamicin & Polyvinyl chloride (PVC), silicone, \\
polyurethane & {$[101]$} \\
\hline
\end{tabular}


Table 2. Cont.

\begin{tabular}{ccc}
\hline Released Antimicrobial Substance & Release Systems & References \\
\hline \multirow{2}{*}{ Triclosan } & Cyclodextrin & {$[103]$} \\
\cline { 2 - 3 } & Hyaluronic acid and chitosan & {$[90]$} \\
\cline { 2 - 3 } & Poly(ethylene terephthalate) & {$[104]$} \\
\cline { 2 - 3 } & Polyacrilonitrile & {$[105]$} \\
\hline Chlorhexidrine & Acrylic bone cements & {$[106]$} \\
\hline Furanones & Polyethylene, polypropylene & {$[107]$} \\
\hline Nitrogen oxide & Silica nanoparticles & {$[108]$} \\
\hline Vancomyzin & Poly(ethylene glycol) & {$[109]$} \\
\hline Tobramycin & (PEG)-acrylate & {$[110]$} \\
\hline Tetracycline hydrochloride & Hydroxyapatite & {$[111]$} \\
\hline Octenidine & Hydroxyapatite and & {$[112]$} \\
\hline Cationic surfactants & polycaprolactone & {$[113]$} \\
\hline Acylase enzyme & Poly(L-lactide) & {$[114]$} \\
\hline Lysozyme enzyme & Poly(methyl methacrylate) & {$[115]$} \\
\hline Halogens & Polydimethyl/vinylmethyl-siloxane & {$[116]$} \\
\hline Antibiotics & Cellulose & \\
\hline
\end{tabular}

Apart from laboratory-scale products, there are commercially available products in the medical field based on antibacterial coatings with release capacity. For instance, Innovotech ${ }^{\circledR}$ developed novel antibacterial medical devices called InnovoSIL ${ }^{\mathrm{TM}}$ Antimicrobial Products incorporating innovative and effective antimicrobial agents in them. This technology is based on $\mathrm{Ag}$ (I) cations and anions which are coordinated with high oxidation state iodine. In fact, this chemical coordination increases mechanism of action against a broad spectrum of bacteria and fungi reducing the likelihood of development of bactericidal resistance and allowing better biofilms penetration of the active agent. When it is coated onto a surface, it kills mature biofilms in less than $24 \mathrm{~h}$ and eliminates remains of microorganisms for one month due to its slow active molecule release capacity over long periods of time [118]. Moreover, Surmodics ${ }^{\circledR}$ have developed a medical device technology, which possesses low molecular-weight therapeutic agents release capacity from coronary stents or intravitreal implants, among others. This technology is composed of a polymeric matrix and a high number of compatible drug classes with anti-proliferative, anti-inflammatory and anti-microbial properties [119]. One last antibacterial medical device should be pointed out is TYRX ${ }^{\mathrm{TM}}$ which was developed by Medtronic ${ }^{\circledR}$. TYRX ${ }^{\mathrm{TM}}$ is an absorbable antibacterial wrap which is the only fully absorbable antibacterial device authorized by the Food and Drug Administration (FDA) for its use in implantable cardiovascular medical devices (ICMD) or implantable neurostimulators (IN) to help prevent infections. In this case, minocycline and rifampicin are released locally for at least 7 days and the wrap is completely absorbed in the body in about 9 weeks. A one-year follow-up study based on TYRX ${ }^{\mathrm{TM}}$ realized to about 500 high risk patients, demonstrated that bacterial infections were reduced by $90 \%$ compared to those patients who did not receive the TYRX ${ }^{\mathrm{TM}}[120]$. 


\subsubsection{Nanopatterned Surfaces with Antibacterial Behaviour}

Apart from the previously mentioned antifouling properties which can be obtained by modifying the topography of medical device surfaces by plasma treatment [121], laser patterning or nanoimprint lithography [122], the bactericidal behaviour of these surfaces can be obtained creating nanopatterns with specific design parameters, dimensions and morphologies. These nanopatterned coatings must have nanoscale parameters due to the demonstrated non-bactericidal behaviour of microscale-patterned surfaces [123].

The critical morphological parameters of nanopatterns are height $(H)$, diameter/width $(D / W)$ and interspacing (iS) which must be controlled to achieve bactericidal properties of medical device surfaces. As a matter of fact, there are lots of studies about the antibacterial properties of nanopatterns with different shapes, morphologies and dimensions. Even so, the most studied bactericidal parameters vary between the following values: $100 \mathrm{~nm}<\mathrm{H}<1000 \mathrm{~nm}, 10 \mathrm{~nm}<\mathrm{D} / \mathrm{W}<300 \mathrm{~nm}$ and iS $<500$ $\mathrm{nm}$ [124].

For example, Dickson et al. [122] fabricated some biomimetic nanopillars on poly(methyl methacrylate) films and E. coli microorganism died after direct contact with nanopillered surfaces. More recently, Bhadra et al. [125] explained that minor variations in the nanoarchitecture of substrates can substantially alter their performance as bactericidal surfaces (Hs ranged from $650 \mathrm{~nm}$ to $100 \mathrm{~nm}$ and iS between 8-12 tips per $\mu \mathrm{m}^{2}$ ). In another study, Hazell et al. [126] concluded that nanocone arrays onto polystyrene show bactericidal activity (30\% percentage of bacterial death) against Escherichia coli and Klebsiella pneumoniae. In fact, it is shown that nanoconed surfaces with cone-to-cone spacing of 200 $\mathrm{nm}$, higher aspect ratios (HAR) and with width tips smaller than $20 \mathrm{~nm}$, kill the major quantity of bacterial communities.

The bactericidal mechanism (Figure 3) of these nanopatterned surfaces is not clear at all but it is believed that the mechanism is based on the disruption of the bacterial cellular membrane due to the strong attachment between bacteria and patterned surfaces which leads to the penetration of high aspect ratio (HAR) nanopatterns, as Modaresifar et al. concluded in their study [124]. There are more studies which support the previously mentioned bacteria killing mechanism. For instance, in 2014 Nowlin and co-coworkers [127] demonstrated that there is evidence which corroborates the idea that nanopatterns induced Saccharomyces cerevisae microbial death through structural and mechanical interactions. Moreover, Ivanova et al. [128] concluded that natural cicada wings nanopillars (200 nm tall, $100 \mathrm{~nm}$ base diameter, $60 \mathrm{~nm}$ diameter upper part and spacing of $170 \mathrm{~nm}$ between nanopatterns) are extremely effective at killing Pseudomonas aureginosa cells by the bactericidal mechanism.

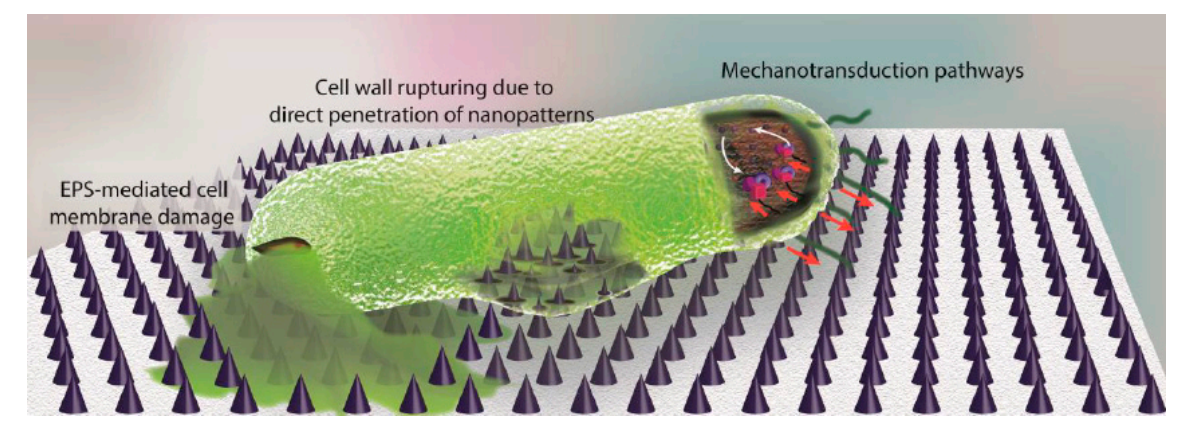

Figure 3. Bacteria killing mechanism of nanopatterned surfaces.

\section{Conclusions and Future Work}

The number of research works devoted to the fabrication of effective antibacterial coatings capable to reduce or inhibit the biofilm formation on substrates of different biomaterials increases year by year. Considering the decrease of antibiotic effectiveness due to superbacteria or antibiotic resistant bacteria worldwide, the development of these antibacterial coatings capable of aborting bacterial proliferation could be considered as one of the most important challenges in research that biomaterials scientists 
must overcome in the near future. In this context, the combination of some of the methodologies described in this review could be an excellent approach to improve the effectiveness of new antibacterial coatings. Multifunctional and multi-approach coatings could be excellent options to overcome some of the actual limitations of the commonly used coatings, such as their specificity. In this review, some of the most promising approaches reported to date have been summarized.

Author Contributions: Conceptualization, J.L.V.-V., L.R.-R. and L.P.-A; writing-original draft preparation, J.A.-D.O., L.P.-A. and L.R.-R.; writing-review and editing, V.S.-M., J.L.V.-V., L.P.-A. and L.R.-R. All authors have read and agreed to the published version of the manuscript.

Funding: This research was funded by Basque Government (ELKARTEK, FRONTIERS), by the Department of Development and Infrastructures of the Basque Country, and by i+Med S. Coop. J. A-O thanks Basque Government for "Program of Industrial Doctorates. Bikaintek 2018" (exp number: 01-AF-W2-2018-00002). V. S. M thanks the funding from the European Union's Horizon 2020 research and innovation programme under the Marie Sklodowska-Curie grant agreement No 795417.

Conflicts of Interest: The authors declare no conflict of interest.

\section{References}

1. Yin, J.; Luan, S. Opportunities and challenges for the development of polymer-based biomaterials and medical devices. Regen. Biomater. 2016, 3, 129-135. [CrossRef] [PubMed]

2. Narayana, S.V.V.S.P.; Srihari, S.V.V.P. A review on surface modifications and coatings on implants to prevent biofilm. Regen. Eng. Transl. Med. 2019. [CrossRef]

3. Ben, M.; Mavri, T.; Kralj-igli, V. The importance of antibacterial surfaces in biomedical applications. Adv. Biomembr. Lipid Self Assem. 2018, 28, 115-165.

4. Langer, R.S.; Lendlein, A. Biodegradable, elastic shape-memory polymers for potential biomedical applications. Science. 2002, 1673-1676. [CrossRef]

5. Sotiropoulos, F.; Borazjani, I. A review of state-of-the-art numerical methods for simulating flow through mechanical heart valves. Med. Biol. Eng. Comput. 2009, 47, 245-256. [CrossRef]

6. Singha, P.; Locklin, J.; Handa, H. A review of the recent advances in antimicrobial coatings for urinary catheters. Acta Biomater. 2017, 50, 20-40. [CrossRef]

7. Gallieni, M.; Giordano, A.; Pinerolo, C.; Cariati, M. Type of peritoneal dialysis catheter and outcomes. J. Vasc. Access 2015, 16, S68-S72. [CrossRef]

8. Mani, G.; Feldman, M.D.; Patel, D.; Agrawal, C.M. Coronary stents: A materials perspective. Biomaterials 2007, 28, 1689-1710. [CrossRef]

9. Jayaswal, G.P.; Dange, S.P.; Khalikar, A.N. Bioceramic in dental implants: A review. J. Indian Prosthodont. Soc. 2010, 10, 8-12. [CrossRef]

10. Xinming, L.; Yingde, C.; Lloyd, A.W.; Mikhalovsky, S.V.; Sandeman, S.R.; Howel, C.A.; Liewen, L. Polymeric hydrogels for novel contact lens-based ophthalmic drug delivery systems: A review. Contact Lens Anterior Eye 2008, 31, 57-64. [CrossRef]

11. Chehade, M.; Elder, M.J. Intraocular lens materials and styles: A review. Aust. N. Z. J. Ophthalmol. 1997, 25, 255-263. [CrossRef] [PubMed]

12. Dormer, K.J.; Gan, R.Z. Biomaterials for implantable middle ear hearing devices. Otolaryngol. Clin. N. Am. 2001, 34, 289-297. [CrossRef]

13. Granchi, D.; Cenni, E.; Trisolino, G.; Giunti, A.; Baldini, N. Sensitivity to implant materials in patients undergoing total hip replacement. J. Biomed. Mater. Res. Part B Appl. Biomater. 2006, 77B, 257-264. [CrossRef] [PubMed]

14. Price, A.J.; Alvand, A.; Troelsen, A.; Katz, J.N.; Hooper, G.; Gray, A.; Carr, A.; Beard, D. Knee replacement. Lancet 2018, 392, 1672-1682. [CrossRef]

15. Barrows, T. Degradable implant materials: A review of synthetic absorbable polymers and their applications. Clin. Mater. 1986, 1, 233-257. [CrossRef]

16. Thamaraiselvi, T.; Rajeswari, S. Biological evaluation of bioceramic materials-a review. Trends Biomater. Artif. Organs 2004, 18, 9-17.

17. Thompson, J.Y.; Stoner, B.R.; Piascik, J.R.; Smith, R. Adhesion/cementation to zirconia and other non-silicate ceramics: Where are we now? Dent. Mater. 2011, 27, 71-82. [CrossRef] 
18. Hisbergues, M.; Vendeville, S.; Vendeville, P. Zirconia: Established facts and perspectives for a biomaterial in dental implantology. J. Biomed. Mater. Res. Part B Appl. Biomater. 2009, 88B, 519-529. [CrossRef]

19. Savvides, N.; Bell, T.J. Hardness and elastic modulus of diamond and diamond-like carbon films. Thin Solid Films 1993, 228, 289-292. [CrossRef]

20. Love, C.A.; Cook, R.B.; Harvey, T.J.; Dearnley, P.A.; Wood, R.J.K. Diamond like carbon coatings for potential application in biological implants-A review. Tribol. Int. 2013, 63, 141-150. [CrossRef]

21. Kohn, D.H. Metals in medical applications. Curr. Opin. Solid State Mater. Sci. 1998, 3, 309-316. [CrossRef]

22. Zhao, L.; Chu, P.K.; Zhang, Y.; Wu, Z. Antibacterial coatings on titanium implants. J. Biomed. Mater. Res. Part B Appl. Biomater. 2009, 91B, 470-480. [CrossRef] [PubMed]

23. Teo, A.J.T.; Mishra, A.; Park, I.; Kim, Y.-J.; Park, W.-T.; Yoon, Y.-J. Polymeric Biomaterials for Medical Implants and Devices. ACS Biomater. Sci. Eng. 2016, 2, 454-472. [CrossRef]

24. Biomedical Composites; Elsevier: Amsterdsm, Holland, 2017; ISBN 9780081007525.

25. Saad, M.; Akhtar, S.; Srivastava, S. Composite polymer in orthopedic implants: A review. Mater. Today Proc. 2018, 5, 20224-20231. [CrossRef]

26. Schulman, A.; Piliero, S.J.; Pentel, L.; Ott, W.R.; Moskowitz, H.D. Composite materials for dental implants. Oral Surg. Oral Med. Oral Pathol. 1975, 40, 183-193. [CrossRef]

27. Zobell, C.E. The effect of solid surfaces upon bacterial activity. J. Bacteriol. 1943, 46, 39-56. [CrossRef]

28. Vasilev, K. Nanoengineered antibacterial coatings and materials: A perspective. Coatings. 2019, 9, 654. [CrossRef]

29. Arciola, C.R.; Campoccia, D.; Speziale, P.; Montanaro, L.; Costerton, J.W. Biofilm formation in Staphylococcus implant infections. A review of molecular mechanisms and implications for biofilm-resistant materials. Biomaterials 2012, 33, 5967-5982. [CrossRef]

30. Bazaka, K.; Jacob, M.V.; Crawford, R.J.; Ivanova, E.P. Efficient surface modification of biomaterial to prevent biofilm formation and the attachment of microorganisms. Appl. Microbiol. Biotechnol. 2012, 95, $299-311$. [CrossRef]

31. Veerachamy, S.; Yarlagadda, T.; Manivasagam, G.; Yarlagadda, P.K. Bacterial adherence and biofilm formation on medical implants: A review. Proc. Inst. Mech. Eng. Part. H J. Eng. Med. 2014, 228, 1083-1099. [CrossRef]

32. Armbruster, C.R.; Parsek, M.R. New insight into the early stages of biofilm formation. Proc. Natl. Acad. Sci. USA 2018, 115, 4317-4319. [CrossRef] [PubMed]

33. Stanley, P.M. Factors affecting the irreversible attachment of Pseudomonas aeruginosa to stainless steel. Can. J. Microbiol. 1983, 29, 1493-1499. [CrossRef] [PubMed]

34. Danese, P.N.; Pratt, L.A.; Kolter, R. Exopolysaccharide production is required for development of Escherichia coli K-12 biofilm architecture. J. Bacteriol. 2000, 182, 3593-3596. [CrossRef] [PubMed]

35. Otto, M. Staphylococcal infections: Mechanisms of biofilm maturation and detachment as critical determinants of pathogenicity. Annu. Rev. Med. 2013, 64, 175-188. [CrossRef]

36. Zhang, X.; Wang, L.; Levänen, E. Superhydrophobic surfaces for the reduction of bacterial adhesion. RSC Adv. 2013, 3, 12003-12020. [CrossRef]

37. Mi, G.; Shi, D.; Wang, M.; Webster, T.J. Reducing bacterial infections and biofilm formation using nanoparticles and nanostructured antibacterial surfaces. Adv. Healthc. Mater. 2018, 7, 1800103. [CrossRef]

38. Watson, G.S.; Green, D.W.; Schwarzkopf, L.; Li, X.; Cribb, B.W.; Myhra, S.; Watson, J.A. A gecko skin micro/nano structure-A low adhesion. Acta Biomater. 2015, 21, 109-122. [CrossRef]

39. Hasan, J.; Crawford, R.J.; Ivanova, E.P. Antibacterial surfaces: The quest for a new generation of biomaterials. Trends Biotechnol. 2013, 31, 295-304. [CrossRef]

40. Chen, S.; Li, L.; Zhao, C.; Zheng, J. Surface hydration: Principles and applications toward low-fouling/nonfouling biomaterials. Polym. Guildf. 2010, 51, 5283-5293. [CrossRef]

41. Song, L.; Sun, L.; Zhao, J.; Wang, X.; Yin, J.; Luan, S.; Ming, W. Synergistic superhydrophobic and photodynamic cotton textiles with remarkable antibacterial activities. ACS Appl. Biol. Mater. 2019, 2, 2756-2765. [CrossRef]

42. Wang, J.; Wang, Z.; Guo, S.; Zhang, J.; Song, Y.; Dong, X.; Wang, X.; Yu, J. Antibacterial and anti-adhesive zeolite coatings on titanium alloy surface. Microporous Mesoporous Mater. 2011, 146, 216-222. [CrossRef]

43. Lin, X.; Yang, M.; Jeong, H.; Chang, M.; Hong, J. Durable superhydrophilic coatings formed for anti-biofouling and oil-water separation. J. Membr. Sci. 2016, 506, 22-30. [CrossRef] 
44. Pinter, B.; Fievez, T.; Bickelhaupt, F.M.; Geerlings, P.; De Proft, F. On the origin of the steric effect. Phys. Chem. Chem. Phys. 2012, 14, 9846-9854. [CrossRef] [PubMed]

45. Park, K.D. Bacterial adhesion on PEG modified surfaces. Biomaterials 1998, 19, 851-859. [CrossRef]

46. Peng, L.; Chang, L.; Liu, X.; Lin, J.; Liu, H.; Han, B.; Wang, S. Antibacterial property of a polyethylene glycol-grafted dental material. ACS Appl. Mater. Interfaces 2017, 9, 17688-17692. [CrossRef]

47. Perrin, F.X.; Nguyen, T.D.H.; Nguyen, D.L. Formation, structure and antibacterial activities of silazane networks grafted with poly (ethylene glycol) branches. Prog. Org. Coatings 2015, 88, 92-105. [CrossRef]

48. Vasilev, K.; Griesser, S.S.; Griesser, H.J. Antibacterial surfaces and coatings produced by plasma techniques. Plasma Process. Polym. 2011, 8, 1010-1023. [CrossRef]

49. Kingshott, P.; Wei, J.; Bagge-Ravn, D.; Gadegaard, N.; Gram, L. Covalent attachment of poly(ethylene glycol) to surfaces, critical for reducing bacterial adhesion. Langmuir 2003, 19, 6912-6921. [CrossRef]

50. Minko, S. Grafting on Solid Surfaces: "Grafting to" and "Grafting from" Methods; Polymer Surfaces and Interfaces; Stamm, M., Ed.; Springer: Berlin, Germany, 2008; ISBN 9783540738640.

51. Zdyrko, B.; Klep, V.; Li, X.; Kang, Q.; Minko, S.; Wen, X.; Luzinov, I. Polymer brushes as active nanolayers for tunable bacteria adhesion. Mater. Sci. Eng. C 2009, 29, 680-684. [CrossRef]

52. Hadjesfandiari, N.; Yu, K.; Mei, Y.; Kizhakkedathu, J.N. Polymer brush-based approaches for the development of infection-resistant surfaces. J. Mater. Chem. B 2014, 2, 4968. [CrossRef]

53. Roosjen, A.; Busscher, H.J.; Norde, W.; Van der Mei, H.C. Bacterial factors influencing adhesion of Pseudomonas aeruginosa strains to a poly (ethylene oxide) brush. Microbiology 2006, 152, 2673-2682. [CrossRef]

54. He, T.; Jańczewski, D.; Jana, S.; Parthiban, A.; Guo, S.; Zhu, X.; Lee, S.S.C.; Parra-Velandia, F.J.; Teo, S.L.M.; Vancso, G.J. Efficient and robust coatings using poly(2-methyl-2-oxazoline) and its copolymers for marine and bacterial fouling prevention. J. Polym. Sci. Part. A Polym. Chem. 2016, 54, 275-283. [CrossRef]

55. Herrwerth, S.; Eck, W.; Reinhardt, S.; Grunze, M. Factors that determine the protein resistance of oligoether self-assembled monolayers-Internal hydrophilicity, terminal hydrophilicity, and lateral packing density. $J$. Am. Chem. Soc. 2003, 125, 9359-9366. [CrossRef]

56. Li, X.; Wu, B.; Chen, H.; Nan, K.; Jin, Y.; Wang, B. Recent developments in smart antibacterial surfaces to inhibit biofilm formation and bacterial infections. J. Mater. Chem. B 2018, 6, 4274-4292. [CrossRef]

57. Weng, X.D.; Ji, Y.L.; Ma, R.; Zhao, F.Y.; An, Q.F.; Gao, C.J. Superhydrophilic and antibacterial zwitterionic polyamide nanofiltration membranes for antibiotics separation. J. Membr. Sci. 2016, 510, 122-130. [CrossRef]

58. Lalani, R.; Liu, L. Electrospun zwitterionic poly (sulfobetaine methacrylate) for nonadherent, superabsorbent, and antimicrobial wound dressing applications. Biomacromolecules 2012, 13, 1853-1863. [CrossRef]

59. Chen, S.; Yuan, L.; Li, Q.; Li, J.; Zhu, X.; Jiang, Y.; Sha, O.; Yang, X.; Xin, J.H.; Wang, J.; et al. Durable antibacterial and nonfouling cotton textiles with enhanced comfort via zwitterionic sulfopropylbetaine coating. Small 2016, 12, 3516-3521. [CrossRef]

60. Timma, L.M.; Lewald, L.; Gier, F.; Homey, L.; Neyer, C.; Nickisch-Hartfiel, A.; Gutmann, J.S.; Oberthür, M. Nonfouling textiles with tunable antimicrobial activity based on a zwitterionic polyamine finish. RSC Adv. 2019, 9, 9783-9791. [CrossRef]

61. He, H.; Xiao, Z.; Zhou, Y.; Chen, A.; Xuan, X.; Li, Y.; Guo, X.; Zheng, J.; Xiao, J.; Wu, J. Zwitterionic poly (sulfobetaine methacrylate) hydrogels with optimal mechanical properties for improving wound healing: In vivo. J. Mater. Chem. B 2019, 7, 1697-1707. [CrossRef]

62. Cheng, G.; Li, G.; Xue, H.; Chen, S.; Bryers, J.D.; Jiang, S. Zwitterionic carboxybetaine polymer surfaces and their resistance to long-term biofilm formation. Biomaterials 2009, 30, 5234-5240. [CrossRef]

63. Kang, S.M.; You, I.; Cho, W.K.; Shon, H.K.; Lee, T.G.; Choi, I.S.; Karp, J.M.; Lee, H. One-step modification of superhydrophobic surfaces by a mussel-inspired polymer coating. Angew. Chem. Int. Ed. 2010, 49, 9401-9404. [CrossRef]

64. Wu, S.; Zhang, B.; Liu, Y.; Suo, X.; Li, H.; Wu, S.; Zhang, B.; Liu, Y.; Suo, X.; Li, H. In fluence of surface topography on bacterial adhesion: A review. Biointerphases 2018, 13, 060801. [CrossRef]

65. Morán, G.; Ramos-Chagas, G.; Hugelier, S.; Xie, X.; Boudjemaa, R.; Ruckebusch, C.; Sliwa, M.; Darmanin, T.; Gaucher, A.; Prim, D.; et al. Superhydrophobic polypyrene films to prevent: Staphylococcus aureus and Pseudomonas aeruginosa biofilm adhesion on surfaces: High efficiency deciphered by fluorescence microscopy. Photochem. Photobiol. Sci. 2018, 17, 1023-1035. [CrossRef] 
66. Boinovich, L.; Emelyanenko, A.M.; Pashinin, A.S. Analysis of long-term durability of superhydrophobic properties under continuous contact with water. ACS Appl. Mater. Interfaces 2010, 2, 1754-1758. [CrossRef] [PubMed]

67. Kim, S.; Jung, U.T.; Kim, S.K.; Lee, J.H.; Choi, H.S.; Kim, C.S.; Jeong, M.Y. Nanostructured multifunctional surface with antireflective and antimicrobial characteristics. ACS Appl. Mater. Interfaces 2015, 7, 326-331. [CrossRef] [PubMed]

68. Privett, B.J.; Youn, J.; Hong, S.A.; Lee, J.; Han, J.; Shin, J.H.; Schoenfisch, M.H. Antibacterial fluorinated silica colloid superhydrophobic surfaces. Langmuir 2011, 27, 9597-9601. [CrossRef] [PubMed]

69. Tiller, J.C.; Liao, C.J.; Lewis, K.; Klibanov, A.M. Designing surfaces that kill bacteria on contact. Proc. Natl. Acad. Sci. USA 2001, 98, 5981-5985. [CrossRef] [PubMed]

70. Kaur, R.; Liu, S. Antibacterial surface design-Contact kill. Prog. Surf. Sci. 2016, 91, 136-153. [CrossRef]

71. Jennings, M.C.; Minbiole, K.P.C.; Wuest, W.M. Quaternary ammonium compounds: An antimicrobial mainstay and platform for innovation to address bacterial resistance. ACS Infect. Dis. 2016, 1, $288-303$. [CrossRef]

72. Sugii, M.M.; de Souza Ferreira, F.A.; Müller, K.C.; Rodrigues Filho, U.P.; Baggio Aguiar, F.H. Quaternary ammonium compound derivatives for biomedical applications. Mater. Biomed. Eng. 2019, 153-175. [CrossRef]

73. Makvandi, P.; Jamaledin, R.; Jabbari, M.; Nikfarjam, N.; Borzacchiello, A. Antibacterial quaternary ammonium compounds in dental materials: A systematic review. Dent. Mater. 2018, 34, 851-867. [CrossRef] [PubMed]

74. Tiller, J.C.; Lee, S.B.; Lewis, K.; Klibanov, A.M. Polymer surfaces derivatized with poly (vinyl-N-hexylpyridinium) kill airborne and waterborne bacteria. Biotechnol. Bioeng. 2002, 79, 465-471. [CrossRef] [PubMed]

75. Nikawa, H.; Ishida, K.; Hamada, T.; Satoda, T.; Murayama, T.; Takemoto, T.; Tamamoto, M.; Tajima, H.; Shimoe, S.; Fujimoto, H.; et al. Immobilization of octadecyl ammonium chloride on the surface of titanium and its effect on microbial colonization in vitro. Dent. Mater. J. 2005, 24, 570-582. [CrossRef] [PubMed]

76. Murata, H.; Koepsel, R.R.; Matyjaszewski, K.; Russell, A.J. Permanent, non-leaching antibacterial surfaces-2: How high density cationic surfaces kill bacterial cells. Biomaterials 2007, 28, 4870-4879. [CrossRef]

77. Chiono, V.; Pulieri, E.; Vozzi, G.; Ciardelli, G.; Ahluwalia, A.; Giusti, P. Genipin-crosslinked chitosan/gelatin blends for biomedical applications. J. Mater. Sci. Mater. Med. 2008, 19, 889-898. [CrossRef]

78. Tan, Y.; Leonhard, M.; Ma, S.; Moser, D.; Schneider-Stickler, B. Efficacy of carboxymethyl chitosan against Candida tropicalis and Staphylococcus epidermidis monomicrobial and polymicrobial biofilms. Int. J. Biol. Macromol. 2018, 110, 150-156. [CrossRef]

79. Onaizi, S.A.; Leong, S.S.J. Tethering antimicrobial peptides: Current status and potential challenges. Biotechnol. Adv. 2011, 29, 67-74. [CrossRef]

80. Thallinger, B.; Prasetyo, E.N.; Nyanhongo, G.S.; Guebitz, G.M. Antimicrobial enzymes: An emerging strategy to fight microbes and microbial biofilms. Biotechnol. J. 2013, 8, 97-109. [CrossRef]

81. Meléndez-Ortiz, H.I.; Alvarez-Lorenzo, C.; Burillo, G.; Magariños, B.; Concheiro, A.; Bucio, E. Radiation-grafting of N-vinylimidazole onto silicone rubber for antimicrobial properties. Radiat. Phys. Chem. 2015, 110, 59-66. [CrossRef]

82. Lim, K.; Chua, R.R.Y.; Saravanan, R.; Basu, A.; Mishra, B.; Tambyah, P.A.; Ho, B.; Leong, S.S.J. Immobilization studies of an engineered arginine-tryptophan-rich peptide on a silicone surface with antimicrobial and antibiofilm activity. ACS Appl. Mater. Interfaces 2013, 5, 6412-6422. [CrossRef]

83. Thoma, L.M.; Boles, B.R.; Kuroda, K. Cationic methacrylate polymers as topical antimicrobial agents against staphylococcus aureus nasal colonization. Biomacromolecules 2014, 15, 2933-2943. [CrossRef] [PubMed]

84. Microban Antimicrobial Medical Device Coatings. Available online: https:/www.microban.com/blog/ antimicrobial-medical-device-coatings (accessed on 3 February 2020).

85. DESSAN Enzymatic. Available online: http://www.ab-laboratorios.com/en/cleaning-and-disinfection/1393desinfectante-sanitario.html (accessed on 3 February 2020).

86. Vasilev, K.; Cook, J.; Griesser, H.J. Antimicrobial surfaces for biomedical devices. Expert Rev. Med. Devices 2009, 6, 553-567. [CrossRef] [PubMed] 
87. Kufner, S.; Cassese, S.; Valeskini, M.; Neumann, F.J.; Schulz-Schüpke, S.; Hoppmann, P.; Fusaro, M.; Schunkert, H.; Laugwitz, K.L.; Kastrati, A.; et al. Long-term efficacy and safety of paclitaxel-eluting balloon for the treatment of drug-eluting stent restenosis: 3-year results of a randomized controlled trial. JACC Cardiovasc. Interv. 2015, 8, 877-884. [CrossRef] [PubMed]

88. Bucolo, C.; Gozzo, L.; Longo, L.; Mansueto, S.; Vitale, D.C.; Drago, F. Long-term efficacy and safety profile of multiple injections of intravitreal dexamethasone implant to manage diabetic macular edema: A systematic review of real-world studies. J. Pharmacol. Sci. 2018, 138, 219-232. [CrossRef] [PubMed]

89. Zander, Z.K.; Becker, M.L. Antimicrobial and antifouling strategies for polymeric medical devices. ACS Macro Lett. 2018, 7, 16-25. [CrossRef]

90. Valverde, A.; Pérez-Álvarez, L.; Ruiz-Rubio, L.; Pacha Olivenza, M.A.; García Blanco, M.B.; Díaz-Fuentes, M.; Vilas-Vilela, J.L. Antibacterial hyaluronic acid/chitosan multilayers onto smooth and micropatterned titanium surfaces. Carbohydr. Polym. 2019, 207, 824-833. [CrossRef]

91. Lv, H.; Chen, Z.; Yang, X.; Cen, L.; Zhang, X.; Gao, P. Layer-by-layer self-assembly of minocycline-loaded chitosan/alginate multilayer on titanium substrates to inhibit biofilm formation. J. Dent. 2014, 42, 1464-1472. [CrossRef]

92. Choi, D.; Heo, J.; Park, J.H.; Jo, Y.; Jeong, H.; Chang, M.; Choi, J.; Hong, J. Nano-film coatings onto collagen hydrogels with desired drug release. J. Ind. Eng. Chem. 2016, 36, 326-333. [CrossRef]

93. Schwartz, V.B.; Thétiot, F.; Ritz, S.; Pütz, S.; Choritz, L.; Lappas, A.; Förch, R.; Landfester, K.; Jonas, U. Antibacterial surface coatings from zinc oxide nanoparticles embedded in poly (N-isopropylacrylamide) hydrogel surface layers. Adv. Funct. Mater. 2012, 22, 2376-2386. [CrossRef]

94. Noimark, S.; Weiner, J.; Noor, N.; Allan, E.; Williams, C.K.; Shaffer, M.S.P.; Parkin, I.P. Dual-mechanism antimicrobial polymer-ZnO nanoparticle and crystal violet-encapsulated silicone. Adv. Funct. Mater. 2015, 25, 1367-1373. [CrossRef]

95. Lyutakov, O.; Hejna, O.; Solovyev, A.; Kalachyova, Y.; Svorcik, V. Polymethylmethacrylate doped with porphyrin and silver nanoparticles as light-activated antimicrobial material. RSC Adv. 2014, 4, 50624-50630. [CrossRef]

96. Ahmad, Z.; Vargas-Reus, M.A.; Bakhshi, R.; Ryan, F.; Ren, G.G.; Oktar, F.; Allaker, R.P. Antimicrobial Properties of Electrically Formed Elastomeric Polyurethane-Copper Oxide Nanocomposites for Medical and Dental Applications, 1st ed.; Elsevier Inc.: Amsterdam, Holland, 2012; Volume 509, ISBN 9780123918581.

97. Lemire, J.A.; Harrison, J.J.; Turner, R.J. Antimicrobial activity of metals: Mechanisms, molecular targets and applications. Nat. Rev. Microbiol. 2013, 11, 371-384. [CrossRef] [PubMed]

98. Tran, P.A.; Hocking, D.M.; O'Connor, A.J. In situ formation of antimicrobial silver nanoparticles and the impregnation of hydrophobic polycaprolactone matrix for antimicrobial medical device applications. Mater. Sci. Eng. C 2015, 47, 63-69. [CrossRef] [PubMed]

99. Lyutakov, O.; Goncharova, I.; Rimpelova, S.; Kolarova, K.; Svanda, J.; Svorcik, V. Silver release and antimicrobial properties of PMMA films doped with silver ions, nano-particles and complexes. Mater. Sci. Eng. C 2015, 49, 534-540. [CrossRef]

100. Tran, P.A.; Webster, T.J. Antimicrobial selenium nanoparticle coatings on polymeric medical devices. Nanotechnology 2013, 24. [CrossRef]

101. Kelson, A.B.; Carnevali, M.; Truong-Le, V. Gallium-based anti-infectives: Targeting microbial iron-uptake mechanisms. Curr. Opin. Pharmacol. 2013, 13, 707-716. [CrossRef]

102. Aquino, R.P.; Auriemma, G.; Mencherini, T.; Russo, P.; Porta, A.; Adami, R.; Liparoti, S.; Porta, G.D.; Reverchon, E.; Del Gaudio, P. Design and production of gentamicin/dextrans microparticles by supercritical assisted atomisation for the treatment of wound bacterial infections. Int. J. Pharm. 2013, 440, 188-194. [CrossRef]

103. Ramos, A.I.; Braga, T.M.; Fernandes, J.A.; Silva, P.; Ribeiro-Claro, P.J.; Almeida Paz, F.A.; de Fátima Silva Lopes, M.; Braga, S.S. Analysis of the microcrystalline inclusion compounds of triclosan with $\beta$-cyclodextrin and its tris-O-methylated derivative. J. Pharm. Biomed. Anal. 2013, 80, 34-43. [CrossRef]

104. Pérez-Álvarez, L.; Ruiz-Rubio, L.; Lizundia, E.; Hernáez, E.; León, L.M.; Vilas-Vilela, J.L. Active release coating of multilayer assembled branched and ionic $\beta$-cyclodextrins onto poly(ethylene terephthalate). Carbohydr. Polym. 2017, 174, 65-71. [CrossRef] 
105. Pérez-Álvarez, L.; Matas, J.; Gómez-Galván, F.; Ruiz-Rubio, L.; León, L.M.; Vilas-Vilela, J.L. Branched and ionic $\beta$-Cyclodextrins multilayer assembling onto polyacrylonitrile membranes for removal and controlled release of triclosan. Carbohydr. Polym. 2017, 156, 143-151. [CrossRef]

106. Rodriguez, L.C.; Palmer, K.; Montagner, F.; Rodrigues, D.C. A novel chlorhexidine-releasing composite bone cement: Characterization of antimicrobial effectiveness and cement strength. J. Bioact. Compat. Polym. 2015, 30, 34-47. [CrossRef]

107. Baveja, J.K.; Willcox, M.D.P.; Hume, E.B.H.; Kumar, N.; Odell, R.; Poole-Warren, L.A. Furanones as potential anti-bacterial coatings on biomaterials. Biomaterials 2004, 25, 5003-5012. [CrossRef] [PubMed]

108. Slomberg, D.L.; Lu, Y.; Broadnax, A.D.; Hunter, R.A.; Carpenter, A.W.; Schoenfisch, M.H. Role of size and shape on biofilm eradication for nitric oxide-releasing silica nanoparticles. ACS Appl. Mater. Interfaces 2013, 5, 9322-9329. [CrossRef] [PubMed]

109. Lawson, M.C.; Shoemaker, R.; Hoth, K.B.; Bowman, C.N.; Anseth, K.S. Polymerizable vancomycin derivatives for bactericidal biomaterial surface modification: Structure-function evaluation. Biomacromolecules 2009, 10, 2221-2234. [CrossRef]

110. Stigter, M.; De Groot, K.; Layrolle, P. Incorporation of tobramycin into biomimetic hydroxyapatite coating on titanium. Biomaterials 2002, 23, 4143-4153. [CrossRef]

111. Kim, H.W.; Knowles, J.C.; Kim, H.E. Hydroxyapatite/poly ( $\varepsilon$-caprolactone) composite coatings on hydroxyapatite porous bone scaffold for drug delivery. Biomaterials 2004, 25, 1279-1287. [CrossRef]

112. Baier, G.; Cavallaro, A.; Friedemann, K.; Müller, B.; Glasser, G.; Vasilev, K.; Landfester, K. Enzymatic degradation of poly (l-lactide) nanoparticles followed by the release of octenidine and their bactericidal effects. Nanomed. Nanotechnol. Biol. Med. 2014, 10, 131-139. [CrossRef]

113. Carmona-Ribeiro, A.M.; de Melo Carrasco, L.D. Cationic antimicrobial polymers and their assemblies. Int. J. Mol. Sci. 2013, 14, 9906-9946. [CrossRef]

114. Ivanova, K.; Fernandes, M.M.; Mendoza, E.; Tzanov, T. Enzyme multilayer coatings inhibit Pseudomonas aeruginosa biofilm formation on urinary catheters. Appl. Microbiol. Biotechnol. 2015, 99, 4373-4385. [CrossRef]

115. Zhou, B.; Li, Y.; Deng, H.; Hu, Y.; Li, B. Antibacterial multilayer films fabricated by layer-by-layer immobilizing lysozyme and gold nanoparticles on nanofibers. Colloids Surfaces B Biointerfaces 2014, 116, 432-438. [CrossRef]

116. Shirai, T.; Shimizu, T.; Ohtani, K.; Zen, Y.; Takaya, M.; Tsuchiya, H. Antibacterial iodine-supported titanium implants. Acta Biomater. 2011, 7, 1928-1933. [CrossRef] [PubMed]

117. Campoccia, D.; Montanaro, L.; Arciola, C.R. A review of the biomaterials technologies for infection-resistant surfaces. Biomaterials 2013, 34, 8533-8554. [CrossRef] [PubMed]

118. InnovoSIL ${ }^{\mathrm{TM}}$ Antimicrobial Products. Available online: https://www.innovotech.ca/products/innovosilantimicrobial-products/ (accessed on 3 February 2020).

119. Surmodics Drug Delivery Coatings. Available online: http://www.surmodics.com/medical-device/coatingtechnologies/drug-delivery-coatings-overview/ (accessed on 3 February 2020).

120. Medtronic TYRX Absorbable Antibacterial Envelope. Available online: https://www.medtronic.com/usen/healthcare-professionals/products/cardiac-rhythm/infection-control/tyrx-antibacterial-envelope.html (accessed on 3 February 2020).

121. Ostrikov, K.; MacGregor-Ramiasa, M.; Cavallaro, A.; Vasilev, K. Bactericidal effects of plasma-modified surface chemistry of silicon nanograss. J. Phys. D Appl. Phys. 2016, 49. [CrossRef]

122. Dickson, M.N.; Liang, E.I.; Rodriguez, L.A.; Vollereaux, N.; Yee, A.F. Nanopatterned polymer surfaces with bactericidal properties. Biointerphases 2015, 10, 021010. [CrossRef]

123. Rodríguez-Hernández, J. Polymers against microorganisms: On the race to efficient antimicrobial materials. Polym. Against Microorg. Race Effic. Antimicrob. Mater. 2016, 1-278. [CrossRef]

124. Modaresifar, K.; Azizian, S.; Ganjian, M.; Fratila-Apachitei, L.E.; Zadpoor, A.A. Bactericidal effects of nanopatterns: A systematic review. Acta Biomater. 2019, 83, 29-36. [CrossRef]

125. Bhadra, C.M.; Werner, M.; Baulin, V.A.; Truong, V.K.; Kobaisi, M.A.; Nguyen, S.H.; Balcytis, A.; Juodkazis, S.; Wang, J.Y.; Mainwaring, D.E.; et al. Subtle variations in surface properties of black silicon surfaces influence the degree of bactericidal efficiency. Nano Micro Lett. 2018, 10, 36. [CrossRef]

126. Hazell, G.; Fisher, L.E.; Murray, W.A.; Nobbs, A.H.; Su, B. Bioinspired bactericidal surfaces with polymer nanocone arrays. J. Colloid Interface Sci. 2018, 528, 389-399. [CrossRef] 
127. Nowlin, K.; Boseman, A.; Covell, A.; LaJeunesse, D. Adhesion-dependent rupturing of Saccharomyces cerevisiae on biological antimicrobial nanostructured surfaces. J. R. Soc. Interface 2014, 12. [CrossRef]

128. Ivanova, E.P.; Hasan, J.; Webb, H.K.; Truong, V.K.; Watson, G.S.; Watson, J.A.; Baulin, V.A.; Pogodin, S.; Wang, J.Y.; Tobin, M.J.; et al. Natural bactericidal surfaces: Mechanical rupture of pseudomonas aeruginosa cells by cicada wings. Small 2012, 8, 2489-2494. [CrossRef]

(C) 2020 by the authors. Licensee MDPI, Basel, Switzerland. This article is an open access article distributed under the terms and conditions of the Creative Commons Attribution (CC BY) license (http://creativecommons.org/licenses/by/4.0/). 